\title{
Exegetical Puzzles and the Mystical Theologies of Gregory of Nyssa and Dionysius the Areopagite
}

\author{
Ann Conway-Jones \\ Department of Theology and Religion, University of Birmingham, \\ Birmingham, UK \\ a.i.conway-jones@blueyonder.co.uk
}

\begin{abstract}
Gregory of Nyssa and Dionysius the Areopagite both contemplate the Exodus narrative of Moses' experiences on Sinai. That narrative is complex, with Moses ascending and descending the mountain several times, sometimes in company, sometimes alone. Gregory follows the biblical twists and turns in Life of Moses; the relevant paragraph in Dionysius' Mystical Theology tells of just one ascent. This article re-examines their dependence on the details of the biblical text, arguing that its exegetical puzzles proved fertile ground for their apophatic insights. Both seize on Exodus 20:21 as symbolising the utter incomprehensibility of God. But they resolve the enigmas of Exodus 33-34 differently. Gregory uses Exodus 33:18-23 as a springboard to his articulation of a never-ending journey into the infinite divine, while Exodus 34:29-35 provides the biblical impetus behind Dionysius' concept of "union."
\end{abstract}

\section{Keywords}

Gregory of Nyssa - Dionysius the Areopagite - Pseudo-Dionysius - mystical theology - apophaticism

The Exodus narrative of Moses' experiences on Mount Sinai proved crucial for the development of Christian mysticism. As Turner argues, the mystical theology of Late Antiquity relied upon two foundational stories: Plato's allegory of the cave in book 7 of The Republic, and Exodus' account of Moses' encounter with God on the summit of Mount Sinai. ${ }^{1}$ Gregory of Nyssa and Dionysius

1 Denys Turner, The Darkness of God: Negativity in Christian Mysticism (Cambridge, 1995) 11-18.

(C) ANN CONWAY-JONES, 2020 | DOI:10.1163/15700720-12341449

This is an open access article distributed under the terms of the CG BY 4 olicense. Brill com04/26/2023 09:39:25AM 
the Areopagite drew upon both Platonist and biblical traditions; indeed, they were among those responsible for the convergence between the two. They are particularly associated with the exploitation of the darkness imagery in LXX Exodus 20:21: "Moyses went into the darkness where God was." 2 This article re-examines their dependence on the details of the biblical text. It argues that these apophatic theologians scrutinised scripture, alert to its difficulties and discrepancies. They stressed the incomprehensibility of God, and the inadequacy of human speech to capture anything of the divine essence; yet scripture gave them permission to reflect on the symbolic possibilities of religious language. They were inspired by exegetical puzzles, elevating them to the status of paradoxes. As will be demonstrated, their engagement with the enigmas of Exodus 33-34 took them in different directions. Gregory used Exodus 33:18-23 as a springboard to his articulation of a never-ending journey into the infinite divine, while Exodus 34:29-35 provided the biblical impetus behind Dionysius' concept of "union."

The book of Exodus is a creative compilation of originally independent traditions. The Sinai narrative in particular is full of repetitions, contradictions, disruptions and inconsistencies. ${ }^{3}$ Moses ascends the mountain eight times, sometimes in company, sometimes alone. ${ }^{4}$ It is also unclear whether Exodus 19-20 and Exodus 24 are to be treated as representations of the same or subsequent events. ${ }^{5}$ In examining the interpretation of this material by Gregory and Dionysius we are not comparing like with like. Gregory's Life of Moses is an entire treatise, first retelling the biblical story (the historia), and then providing an allegorical commentary (the theoria). ${ }^{6}$ Gregory omits certain episodes,

2 Translations of the Lxx into English are from Albert Pietersma and Benjamin G. Wright, A New English Translation of the Septuagint and the Other Greek Translations Traditionally Included under That Title (Oxford, 2007). English translations of the MT are from the NRSV.

3 See Baruch Schwartz, "What Really Happened at Mount Sinai? Four Biblical Answers to One Question," Bible Review 13, no. 5 (1997) 20-30, 46; or Benjamin D. Sommer, "Revelation at Sinai in the Hebrew Bible and in Jewish Theology," Journal of Religion 79 (1999) 422-51. Schwartz assigns the narratives discussed here to the following Pentateuchal sources: Ex 19:2b-25 (theophany) - a patchwork of J and E; Ex 20:18-26 (the people's fear and Moses drawing near to the "thick darkness") - E; Ex 24:9-11 (the elders' vision) - J; Ex 24:15-18 (the glory of the Lord settling on Mount Sinai and Moses entering the cloud) - P; Ex 25-28 (tabernacle instructions) - P; Ex 33:12-23 (Moses to stand in the hole of the rock) - J; Ex 34:29-35 (Moses' transformation) - P. However, there is little scholarly agreement on the sources of the Sinai narrative.

4 Ex 19:3-7, 8-14, 20-25; 20:21-24:3; 24:9-11, 24:12-32:15; 32:30-34; 34:1-29.

5 See Sommer, "Revelation at Sinai," 436.

6 The text of Life of Moses is taken from Jean Daniélou, Grégoire de Nysse: La Vie de Moïse, ou Traité de la perfection en matière de vertu, $3^{r d}$ ed., SC ${ }^{\text {bis }}$ (Paris, 2000); and, unless stated otherwise, the English translation from Abraham J. Malherbe and Everett Ferguson, Gregory of Nyssa: The Life of Moses (New York, 1978). 
but, by and large, is faithful to the biblical outline of Moses' story. Life of Moses relates three principal theophanies: the burning bush (1.20; 2.19-26); the darkness, within which is revealed the tabernacle not made with hands $(1.46-56$; 2.162-201); and Moses' vision, from within a hole in a rock covered by God's hand, of "the back of the One who called him" (2.219-255). ${ }^{7}$ The material from Dionysius, by contrast, consists of one paragraph in Mystical Theology, itself a very short treatise on apophatic theology. ${ }^{8}$ He collapses Moses' multi-faceted experience into one archetypal ascent. Rorem has demonstrated that his terminology corresponds to the liturgical experience of the hierarch, for whom Moses is the prototype. ${ }^{9}$ In Louth's words, "Dionysios is concerned with the cosmic order disclosed by the biblical revelation and celebrated in the Christian liturgy."10 According to Dionysius, Moses' experience consisted of three stages: purification, contemplation, and union, thus corresponding to "the spiritual ascent from purification to illumination and perfection discussed so often in the hierarchical treatises."11 Despite this difference in genre between Life of Moses and Mystical Theology, a comparison of their respective appropriations of the biblical text is not only possible but profitable. The structure of Mystical Theology 1.3 will be taken as the point of departure.

\section{Purification}

Dionysius begins with Moses being commanded to submit to purification and depart from those who have not undergone it. Rorem points out that the rare term Dionysius uses for Moses' purification ( $\dot{\alpha} \pi \circ x \dot{\alpha} \theta \alpha \rho \sigma \varsigma)$ is used in The Ecclesiastical Hierarchy "for the ritual handwashing of the hierarch and

$7 \quad$ Vit. Moys. 2.220 .

$8 \quad$ MT 1.3; Günter Heil and Adolf Martin Ritter, Corpus Dionysiacum II: Pseudo-Dionysius Areopagita: De coelesti hierarchia, de ecclesiastice hierarchia, de mystica theologia, epistulae, PTS 36 (Berlin, 1991) 143.8-144.15 (PG 3.100oB-1001A). The English translation of Dionysius' works, unless stated otherwise, is taken from Colm Luibheid and Paul Rorem, Pseudo-Dionysius: The Complete Works (New York, 1987).

9 Paul Rorem, "Moses as the Paradigm for the Liturgical Spirituality of Pseudo-Dionysius," in Elizabeth A. Livingstone (ed.), Papers Presented at the Ninth International Conference on Patristic Studies Held in Oxford 1983: Critica, Classica, Ascetica, Liturgica (Leuven, 1989) 275-9.

10 Andrew Louth, "Mysticism: Name and Thing," Archaeus: Studies in the History of Religions 9 (2005) 9-21, 15.

11 Paul Rorem, Pseudo-Dionysius: A Commentary on the Texts and an Introduction to Their Influence (New York, 1993) 190. 
of the priests in their liturgical cleansing or purification."12 In Exodus 19, God

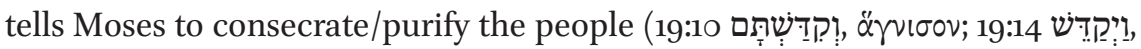
iं $\left.\gamma^{\prime} \alpha \sigma \varepsilon v\right)$, and to set limits preventing them from trespassing onto the mountain (19:12). God later issues additional instructions that priests should be

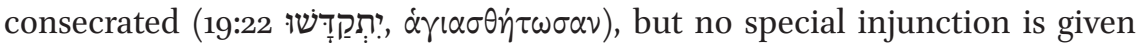
to Moses. Exodus 24 makes no mention of purification, but does present a more coherent stratification, corresponding to the layout of the tabernacle: the people remain at the foot of the mountain by the sacrificial altar (24:3-8), the elders ascend part way up (24:9-11), and Moses reaches the peak, equivalent to the holy of holies (24:15-18). In Mystical Theology 1.3, Dionysius ignores the people's consecration, although Golitzin argues that Exodus' picture of "a people both chosen and gathered about the frontiers of a holy place yet not granted complete entrance within it" must have reminded Dionysius of the "purified and illumined laity" described elsewhere in his work. ${ }^{13}$ Dionysius' structuring of Moses' ascent does, however, reflect the tripartite stratification of Exodus 24. In the historia of Life of Moses, Gregory talks of the divine power initiating ( $\left.\mu \nu \sigma \tau \alpha \gamma \omega \gamma \circ v^{\sigma} \eta \eta^{\prime}\right)$ all the people along with their leader, although he then specifies that only purified men were allowed to approach the mountain. ${ }^{14}$ In the theoria, he interprets this purification in terms of surpassing "the knowledge which originates with the senses," in order to approach "the ascent to lofty perceptions." 15

\section{Trumpets and Lights}

In Mystical Theology, once Moses has been purified, he "hears the many-voiced trumpets" and "sees the many lights." ${ }^{16}$ A sentence or two earlier Dionysius has said that the cause of all is made manifest only to those who "leave behind them every divine light, every sound, every word from heaven."17 Harrington comments,

$12 \quad M T 1.3$ (PTS 36.143.19; PG 3.1000C); Rorem, "Moses as the Paradigm for the Liturgical Spirituality of Pseudo-Dionysius," 276-7.

13 Alexander Golitzin, Mystagogy: A Monastic Reading of Dionysius Areopagita (Collegeville, Minn., 2013) 230-1.

14 Vit. Moys. 1.42. See also Cant. 1 (GNo 6.25.16-26.4); 3 (GNo 6.71.8-18).

15 Vit. Moys. 2.156.

$16 \quad$ MT 1.3 (PTS 36.144.1; PG 3.100oD).

$17 \quad M T 1.3$ (PTS 36.143.15-16; PG 3.100oC); Luibheid's translation amended. 
As in the church, so here, the sensuous participation in the divine is common to all of the laity. The nave of the church blends with the slopes of the mountain, as Moses and "the masses" together experience the sensuous manifestation of God. ${ }^{18}$

But, as Rorem points out, the Dionysian hierarch should know "how to transcend the bare sounds of the scriptures and the physical lights of the liturgy."19 The lights that Dionysius refers to, which he describes as "flashing forth pure

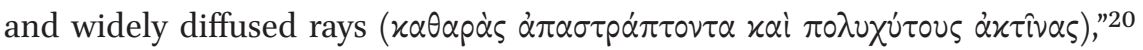
correspond to the lightnings of Exodus 19:16 (ברקים; $\dot{\alpha} \sigma \tau \rho \alpha \alpha i)$ and the flashes of 20:18 (הלפידם; ז's $\lambda \alpha \mu \mu \pi \dot{\delta} \delta \alpha \varsigma)$, neither of which Gregory mentions, talking only of "a fire shining out of the darkness," which "hovered all around the sides of the mountain," drawing on Exodus 19:18. ${ }^{21}$ The auditory phenomena of Exodus 19 include a number of voices: "voices" usually interpreted as thunder (קלת קלוi), " 19:19 קול השופר This raises the question of whether the people heard speech with content or merely terrifying noises. ${ }^{23}$ Deuteronomy 4:12 specifies that the Israelites heard

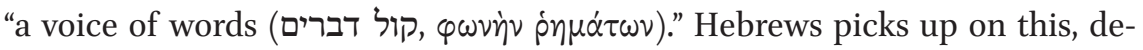
scribing the Sinai theophany as "a blazing fire, and darkness, and gloom, and a tempest, and the sound of a trumpet, and a voice of words which made the hearers beg that not another word be spoken to them." ${ }^{24}$ In Exodus, the people are afraid, and ask Moses to act as intermediary (20:18-21). Gregory combines the trumpet sound with the voice of God:

18 L. Michael Harrington, Sacred Place in Early Medieval Neoplatonism (New York, 2004) 118.

19 Rorem, Pseudo-Dionysius: A Commentary, 19o. Rorem references DN 4.11 (PTS 33.156; PG 3.708C) and $\mathrm{CH} 1.3$ (PTS 36.9; PG 3.121 D).

$20 \quad M T 1.3($ PTS $36.144 .1-2$; PG 3.100oD); my translation.

21 Vit. Moys. 1.43.

22 By translating קל ( $\left.\varphi \omega \nu \eta^{\prime}\right)$ as either "thunder" or "blast," the NRSv obscures these references to voices. There are discrepancies between the MT and the LXX. MT 19:13b reads "When the trumpet (שפר not (שפל) sounds a long blast, (the people) may go up on the mountain," which doesn't fit with the rest of the chapter. The Lxx changes it to "Whenever the sounds and the trumpets (note plural) and the cloud leave the mountain, they shall come up the mountain." мт 20:18 reads "When all the people witnessed the thunder (הקולת the voices) and lightning, the sound of the trumpet ..." The Lxx replaces "voices" by "the voice," possibly thinking of the voice of God.

23 See Sommer, "Revelation at Sinai," 428.

24 Heb 12:18-19, NRSV amended. 
A terrible sound ( $\varphi \omega v \hat{\varsigma})$ ripped down from above upon everything below ... Its sound ( $\dot{\eta} \times \hat{\eta} \varsigma)$ was like the blaring of trumpets, but the intensity and terribleness of the sound ( $\varphi \omega \nu \eta \hat{s})$ surpassed any such com-

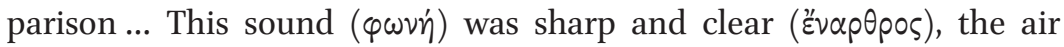
articulating the word by divine power without using organs of speech..$^{25}$

This picture is influenced not only by the "voice of words" in Deuteronomy and Hebrews, but also by Philo's description of the "invisible sound" which "giving shape and tension to the air and changing it to a flaming fire, sounded forth like the breath through a trumpet an articulate ( $\left.\varepsilon^{\prime \prime} v \alpha p \theta p o v\right)$ voice so loud that it appeared to be equally audible to the farthest as well as the nearest."26 Gregory goes on to report the people's fear, caused by this terrible sound, and Moses' courage in approaching the darkness alone. ${ }^{27}$ In his theoria, he interprets the sound of the trumpet(s) ${ }^{28}$ firstly as "the mystery of the incarnation," trumpeted by the Law, the Prophets and finally the Gospels; ${ }^{29}$ and secondly as "the wondrous design of the heavens" proclaiming "the wisdom revealed in all that exists, along with the great glory of God made manifest through visible phenomena." ${ }^{30}$ In both these interpretations, the trumpet sound represents knowledge available to all; yet "the multitude was not capable of hearing the voice from above but relied on Moses to ... teach the people whatever doctrine he might learn through instruction from above." ${ }^{31}$ Gregory thus reflects the ambiguity in Exodus over how much the people heard. Exodus 20:1, introducing the Ten Commandments, does not specify to whom God spoke. Did the people hear the Decalogue, or was it addressed to Moses alone?32 Dionysius too fudges the issue, in that only Moses, once purified, is said to hear the trumpets and see the lights; but this comes before he has stood apart from the crowd. Gregory equates Moses' pre-eminence with the church's arrangement:

25 Vit. Moys. 1.44.

26 Decal. 33. Texts and translations of Philo are from F. H. Colson, G. H. Whitaker, and R. Marcus, Philo in Ten Volumes (and Two Supplementary Volumes), LCL (London, 1929-62).

27 Vit. Moys. 1.45-46.

28 Gregory uses the singular in 1.44, 2.158, 168 (x2); and the plural in 1.44, 2.152, 158, 159, 167 .

29 Vit. Moys. 2.158-9.

30 Vit. Moys. 2.168; my translation.

31 Vit. Moys. 2.16o.

32 See Sommer, "Revelation at Sinai," $428-432$. Sommer points out that the Alexandrinus codex of the Lxx adds "to Moses," whereas the Old Latin has "to the people." The answer to the question of how much the people heard also depends on whether the conversation in 20:15-19 is understood to have taken place before, during, or after the giving of the Ten Commandments. 
Not all thrust themselves toward the apprehension of the mysteries, but, choosing from among themselves someone who is able to hear things divine, they give ear gratefully to him ... ${ }^{33}$

Gregory, like Dionysius, adopts Moses not as a model for any human soul, but for privileged authority figures. Moses' separation from the people is key for both writers, although Dionysius stresses the process of purification, and Gregory the people's fear, and inability to make sense of the trumpet sound.

\section{Contemplation}

From Exodus 19, Dionysius moves on to Exodus 24, and an episode omitted by Gregory. This is when "the masses" are left behind. ${ }^{34}$ According to the MT, Moses, Aaron, Nadab, Abihu and seventy elders went up and "saw the God of Israel." 35 According to the LXX, the chosen of Israel "saw the place, there

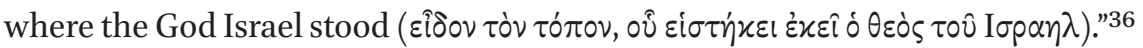
The translators probably took their cue from the mention of God's feet, under which "was something like a pavement of sapphire stone, like the very heaven for clearness." ${ }^{37}$ This is clearly the episode Dionysius is referring to, given his mention of the accompanying priests and his statement that Moses contem-

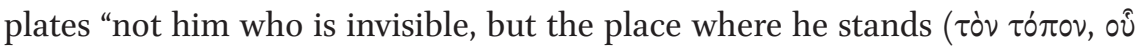
है $\sigma \tau \eta) . " 38$ Although passed over by Gregory, Evagrius of Pontus uses this passage to symbolise the highest reaches of contemplation, when the mind sees "its own state in the time of prayer resembling sapphire or the colour of heaven."39

33 Vit. Moys. 2.160.

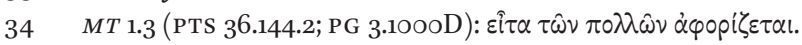

35 Ex 24:10.

36 LXX Ex 24:10. In MT 24.11 the group are described as אצילים, a term which only occurs here, usually translated "leaders." The Lxx translators seem to have connected it with the root אצל - to set apart, and thus rendered it as ह̇ $\pi \dot{i} \lambda \varepsilon \varkappa \tau 0$ - "chosen," "elect."

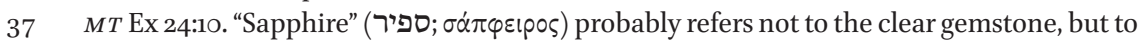
lapis lazuli, a stone prized for its deep intense blue, which often includes minute golden pyrite crystals, reminiscent of stars shimmering in the night sky.

$38 \quad M T 1.3$ (PTS 36.144.4-5; PG 3.100oD). Luibheid's translation - "where he dwells" obscures the biblical reference.

39 Thoughts 39; trans. Robert E. Sinkewicz, Evagrius of Pontus: The Greek Ascetic Corpus, oECS (Oxford, 2003), 180. The word "colour ( $\chi \rho \hat{\omega} \mu \alpha)$ " does not occur in LXX Ex 24:10. Evagrius may have taken it from Symmachus' translation. See Alison Salvesen, Symmachus in the Pentateuch, Jss Monograph 15 (Manchester, 1991) 105-6. 
Whereas Evagrius picks up on the colour of the "place," Dionysius notes its po-

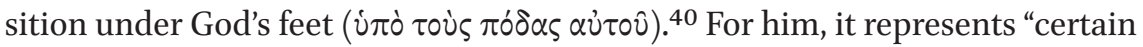
underlying structures of things subordinate to the one who surpasses all things

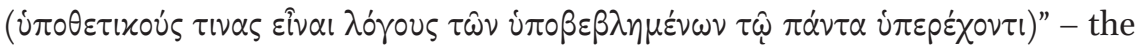
furthest that the mind can reach. ${ }^{41}$ This is reminiscent of Philo's interpreta-

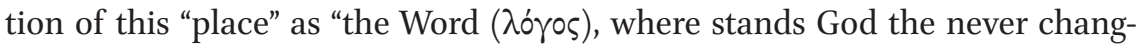
ing, never swerving." ${ }^{42}$ It corresponds, in other words, to the Platonic realm of Forms, the kosmos noêtos. ${ }^{43}$ Philo also associates this realm with the heavenly tabernacle, ${ }^{44}$ an association made easy by the LXx's use of the term paradeig$m a$ in Exodus 25:9, where God tells Moses, "In accordance with all that I show

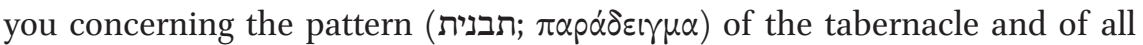
its furniture, so you shall make it." The same word is used by Plato in Timaeus 28-9 to designate the model after which the Demiurge constructed the universe. In Questions on Exodus Philo implies that the pattern of creation and the pattern of the tabernacle are one and the same, ${ }^{45}$ which ties in with the elaborate cosmological symbolism given to the tabernacle, as detailed by both Philo and Josephus. ${ }^{46}$ Gregory refers to the heavenly tabernacle as $\tau \dot{0}$... $\tau \hat{\eta} \varsigma$

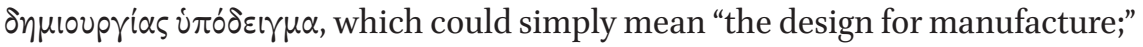
but he may be playing on words, and referring to the tabernacle's cosmological symbolism. ${ }^{47}$ In his theoria, as Daniélou points out, Platonic Ideas are replaced by angels:

Le monde réel pour Grégoire, c'est (le plérôme des créatures spirituelles), composé des cent mondes angéliques. C'est cela qui remplace chez lui le monde intelligible de Platon, comme constituent le monde réel, par opposition à l'illusion cosmique, mais en même temps comme un monde créé qui s'oppose radicalement à Dieu. ${ }^{48}$

$40 \quad$ LXX Ex 24:10.

$41 \quad$ MT 1.3 (PTS 36.144.6-7; PG 3.100oD); trans. Harrington, Sacred Place, 119. Luibheid translates the phrase as the "rationale which presupposes all that lies below the Transcendent One:" Luibheid and Rorem, Pseudo-Dionysius, 137. Golitzin has "certain basic principles of the things subordinate to Him Who transcends all things:" Golitzin, Mystagogy, 38 .

42 Conf. 96; cf. Somn. 1.62.

43 For the relationship between Philo's logos and the kosmos noètos see Opif. 20, 25, 36.

44 See Mos. 2.74, 76.

45 See $Q E 2.5^{2}, 82$. Philo's version of the LXX appears to have $\pi \alpha \rho \alpha \dot{\delta} \varepsilon \downarrow \gamma \mu \alpha$ (rather than $\tau \dot{\pi} \pi \circ$ ) in Ex 25:40, as well as in 25:9, see Leg. 3.102.

46 Mos. 2.71-108; A.J. 3.179-183.

$47 \quad$ Vit. Moys. 1.51 .

48 Jean Daniélou, Platonisme et théologie mystique: Doctrine spirituelle de Saint Grégoire de Nysse, 2nd ed. (Paris, 1954) 162. 
So Gregory associates the tabernacle furniture with "the supercosmic pow-

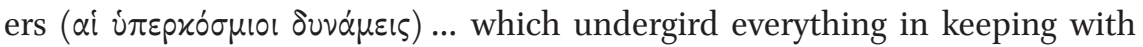
the divine will." 49 The altars, in particular, suggest to him "the adoration by heavenly beings which is continuously performed in this tabernacle."50 This angelogical interpretation is dovetailed with the tabernacle as a type of Christ. The earthly tabernacle is the body of Christ, the Church, the human worshipping community. Dionysius never refers explicitly to the tabernacle in Mystical Theology, although there may be an implicit allusion in his opening prayer, which mentions "treasures beyond all beauty ( $\tau \hat{\omega} \nu \dot{\nu} \pi \varepsilon p x \alpha \dot{\lambda} \lambda \omega \nu \dot{\alpha} \gamma \lambda \alpha i \ddot{\omega} \nu) ; "$;1 and, as already pointed out, his threefold structuring of Moses' ascent corresponds to the tabernacle layout. Using Exodus 24:9-11 instead as the biblical image for the highest contemplation that the human mind can achieve suits his liturgical correspondence, as it enables the priests to be present with the hierarch at this second stage. De Andia argues that Dionysius suppresses God's command to Moses to build a sanctuary according to the prescribed paradigm, substitut-

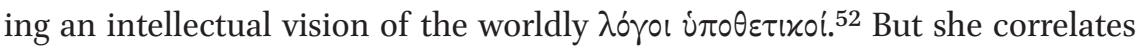
these with a phrase from The Divine Names: the "semblances of (God's) divine

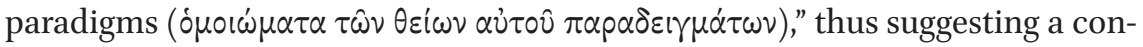
cealed link with Exodus 25:9 after all. ${ }^{33}$ Golitzin argues that the logoi represented by the "place" are not only the divine reasons underlying creation, but also "the 'holy principles ( $\dot{\alpha} p \chi \alpha i)$ of things accomplished' on and around the Church's altar" - the rites of the Church. Through contemplating these "we arrive at the intuition of the angelic hierarchies." ${ }^{.4}$ He shows "the ecclesiastical hierarchy and its heart, the altar, to be the $\sigma \dot{u} \mu \beta 0 \lambda$ ov or sixw' where the worlds of matter and spirit, of humans and angels, of Creator and creature meet and join. There, at the altar, the angels serve. ${ }^{55}$ Similarly, Harrington argues,

The underlying structures of things are themselves beings, but the exemplary instances of beings ... The highest of all lives, as Dionysius explains to us repeatedly, are the upper angelic orders. And indeed, in $\mathrm{On}$ the Heavenly Hierarchy, Dionysius refers to the angels as "the divine place of the godhead's rest." It is the angelic minds, then, that give us the presence of God himself in the Mystical Theology ...

49 Vit. Moys. 2.179; my translation.

$50 \quad$ Vit. Moys. 2.182; my translation.

$51 \quad$ MT 1.1 (PTS 36.142.3-4; PG 3.997B).

52 Ysabel de Andia, Henosis: L'union à Dieu chez Denys l'Aréopagite (Leiden, 1996) 370.

$53 \quad$ DN 7.3; B. R. Suchla, Corpus Dionysiacum I: Pseudo-Dionysius Areopagita: De divinis nominibus, PTS 33 (Berlin, 199o) 197.22 (PG 3.869D); de Andia, Henosis, 346, 370.

54 Golitzin, Mystagogy, 235; quoting EH 3.2 (PTS 36.81.12; PG 3.428A).

55 Ibid., 302. 
He concludes that "the contemplation of the place where God stood is none other than the hierarch's contemplation of the intelligible structures while standing at the divine altar." 56 In other words, rather than contrasting Gregory and Dionysius, as does de Andia, Golitzin and Harrington suggest correspondences between Gregory's understanding of the tabernacle and Dionysius' interpretation of the "place." Despite focussing on different biblical texts, both Gregory and Dionysius represent Moses as ascending to contemplate the angelic structures underlying human worship. As they contemplate his progress beyond this, however, their interpretations of the biblical material take them in different directions.

\section{Dazzling Darkness}

Unlike Evagrius, Dionysius does not take contemplation of the "place" of God as the climax of the spiritual journey. Moses is set free "from what sees and is seen" and "plunges into the truly mysterious darkness of unknowing." ${ }^{77}$ In Exodus 24:15-18, Moses does indeed leave the elders behind to go up into the mountain of God, but there is no mention of darkness - only cloud (ענן; עש

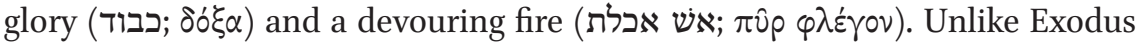
19, there are no auditory phenomena, thus fitting with Dionysius' reference to "hidden silence" at the beginning of Mystical Theology - by this stage, all words have been left behind. ${ }^{58}$ For "darkness," Dionysius goes back to LXx Exodus 20:21. The Hebrew term in this verse (ערפל) has been translated as caligo (mist, fog; Vulgate); "thicke clowde" (Tyndale); "thick darkness" (KJV, NRSV); and "dark cloud" (Јв). ${ }^{59}$ Symmachus used óí $\chi \lambda \eta$ (mist, fog); but the LXX simply has rvó yos (darkness) ${ }^{60}$ So there is no "darkness" as such in MT Exodus 20:21, and Dionysius is right to equate that verse with the "cloud" of Exodus 24:15-18.

56 Harrington, Sacred Place, 119; quoting $\mathrm{CH} 7.4$ (PTS 36.32.7-8; PG 3.212C).

$57 \quad M T 1.3$ (PTS 36.144.9-11; PG 3.1001A).

$5^{8} \quad$ MT 1.1 (PTS 36.142.2; PG 3.997B). Schwartz argues, "In P no words are spoken, no Decalogue or other such sample of divine law is proclaimed. Further, nature does not participate: no thunder, lightning, horns, fire, or smoke are present:" Baruch J. Schwartz, "The Priestly Account of the Theophany and Lawgiving at Sinai," in Michael V. Fox et al. (eds), Texts, Temples and Traditions: A Tribute to Menahem Haran (Winona Lake, Ind., 1996) 103-34, 125 .

59 This is the one occurrence of ערפל in Exodus. It also comes in 1 Kgs 8:12 (= 2 Ch 6:1), where Solomon characterises God as dwelling in the "thick darkness" of the holy of holies.

6o See John William Wevers, Notes on the Greek Text of Exodus, sBuscs 30 (Atlanta, 199o) 317 n.15. 
In the Priestly material of Exodus, such as $24: 15^{-18}$, or the filling of tabernacle in 40:34, God's presence manifests itself as an unspeakably bright and dangerous light, referred to as "glory (כבד),", surrounded by a protective cloud. ${ }^{61}$ This is slightly different from the storm imagery of biblical material originating earlier, in which "the cloud and fire are only the attendant signs of God's terrifying and overwhelming power (Exod. 19:16-18; Ps. 97:2-3, etc.), not component parts of the divine manifestation, nor indispensable features of the divine apparition."62 It is the Priestly cloud which gives rise to the "darkness" of which Dionysius speaks. He mentions gnophos six times in Mystical Theology. ${ }^{63}$ Gregory comments on Exodus 20:21 in Life of Moses 2.162-164; and alludes to the verse eight other times in Life of Moses, and three times in Homilies on the Song of Songs. ${ }^{64}$ Dionysius also refers three times to skotos, once quoting LXX Psalm 17:12: "And

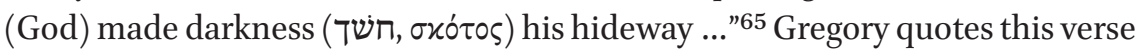
in both Life of Moses and Homelies on the Song of Songs, ${ }^{66}$ which de Andia sees as key evidence for Gregory's influence on Dionysius. ${ }^{67}$ Other than when quoting this Psalm, Gregory associates skotos with evil and wickedness; ${ }^{68}$ but he consistently interprets gnophos as symbolising "the unknown and unseen." 69 What Moses is seeking "transcends all knowledge, cut off on all sides by incomprehensibility, as by a kind of darkness." ${ }^{70}$ This interpretation of Exodus 20:21 goes back to Philo, who describes the fruitlessness of Moses' quest, out of which Moses sees precisely this, "that the God of real Being is ... incapable of being seen."71

61 See Benjamin D. Sommer, The Bodies of God and the World of Ancient Israel (Cambridge, 2009) 68.

62 Moshe Weinfeld, Deuteronomy and the Deuteromonic School (Oxford, 1972) 201.

63 PTS 36.142.2 (PG 3.997B); 143.16 (1000C); 144.10 (1001A); 145.1 (1025A); 145.13 (1025B); 147.9 (1033B).

64 Vit. Moys. 1.46, 56, 58; 2.152, 169, 229, 312, 315; Cant. 6 (GNO 6.181.6), 11 (GNO 6.322.12-323.9); 12 (GNo 6.355.12). The roọ́os he refers to in Vit. Moys. 1.43, Cant. 1 (GNo 6.26.9), and 3

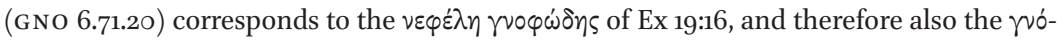

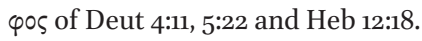

65 PTS 36.142.10 (PG 3.100OA); 142.15 (1000A), where Dionysius quotes LXX Ps 17:12; 150.4

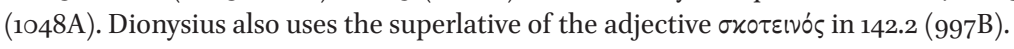

66 Vit. Moys. 2.164; Cant. 6 (GNo 6.181.7-8).

67 De Andia, Henosis, 336. Origen had already associated Lxx Psalm 17:12 with Ex 20:21 (see Cels. 6.17), although his interpretation differs from Gregory's.

68 Vit. Moys. 1.5; 2.80-82, 88, 162, 318.

69 Vit. Moys. 2.169; cf. Cant. 11 (GNO 6.323.3-9).

70 Vit. Moys. 2.163; my translation.

71 Post. 15 cf. Mut. $7-8$. 
In Homilies on the Song of Songs 11, Gregory writes:

The revelation of God to the great Moses began with light as its medium, but afterwards God spoke to him through the medium of a cloud, and when he had become more lifted up and more perfect, he saw God in darkness. ${ }^{72}$

The "light" obviously refers to the burning bush. The "cloud" does not refer to the cloud on Mount Sinai, but to the pillar of cloud which guided and shaded the Israelites. ${ }^{73}$ The "darkness" undoubtedly refers to Exodus 20:21, which Gregory goes on to quote. Daniélou positioned this summary of Moses' ascent, from light to darkness, at the beginning of his highly influential study Platonisme et théologie mystique, first published in $1944 .{ }^{74}$ He structured his exposition of Gregory's "doctrine spirituelle" around three stages - light/purification, cloud/contemplation, and darkness/love - despite conceding that these are not an obvious feature of Life of Moses. ${ }^{75}$ In Life of Moses, darkness is not the climax of Moses' ascent. Once there, he receives, firstly, teachings on "fitting notions about the divine nature" and on "correct ways of behaving" (in other words, the Ten Commandments) and, secondly, a vision of the tabernacle not made with hands. ${ }^{76}$ There, says Gregory, "the one who is elevated through such ascents truly arrives at the limit ( $\pi \dot{\varepsilon}$ pas)." ${ }^{77}$ And yet it is by no means the end of Moses' journey. He comes down the mountain to face the golden calf. ${ }^{78}$ After the Levites have killed their Israelite brothers, ${ }^{79}$ and new stone tablets have been produced, ${ }^{80}$ another high point occurs when Moses requests that God appear to him. ${ }^{81}$

72 Cant. 11 (GNO 6.322.9-12). All translations of Homilies of the Song of Songs are from Richard A. Norris, Gregory of Nyssa: Homilies on the Song of Songs, sBlwAW 13 (Atlanta, 2012).

73 Exodus 13:21-22. See Vit. Moys. 1.30-31, 34-35, 41; 2.121, 124, 135, 153, 229, 315.

74 Daniélou, Platonisme et théologie mystique, 18-19.

75 Ibid., 22.

76 Vit. Moys. 1.47-49, my translation; 2.165-167.

77 Vit. Moys. 2.167; my translation. Despite this, Daniélou places the tabernacle in the second stage - cloud/contemplation - of Moses' ascent. See Daniélou, Platonisme et théologie mystique, $162-72$.

78 Ex 32:15-20; Vit. Moys. 1.58-59, 2.202-203.

79 Ex 32:25-29; Vit. Moys. 1.6o, 2.204-213.

8o Ex 34:1-5; Vit. Moys. 1.6o, 2.214-216.

81 Ex 33:13/18; Vit. Moys. 2.219. Note that Gregory reverses the biblical order here. 
Gregory occasionally uses paradoxical language, such as "the seeing which

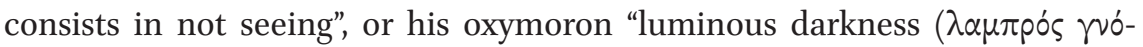

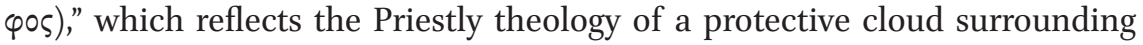
overpowering divine brilliance. ${ }^{82} \mathrm{He}$ is also blending Moses' experience on Mount Sinai with Plato's allegory of the philosopher's ascent to knowledge, in which the prisoner escaping the cave emerges into blinding light. In Epistle 5, Dionysius states, "The divine darkness is that "unapproachable light" where God is said to live." ${ }^{33}$ As Vanneste points out, he is combining "unapproachable light" from 1 Tim 6:16 with elements from Lxx 3 Kings 8:53: "(the Lord) said that he should dwell in darkness." ${ }^{4}$ Similarly, in Divine Names, he posits "intangible and invisible darkness of that Light which is unapproachable because it so far exceeds the visible light." 85 Dionysius takes Gregory's use of paradox to another level. The opening prayer of Mystical Theology exemplifies his "hyperphatic" language, which attempts to transcend both affirmation and negation (the prefix i $\pi \dot{p}$ occurs ten times). The mysteries of theology are said

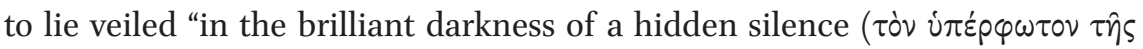

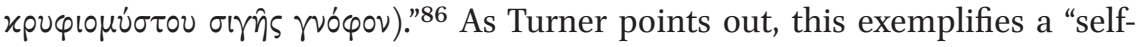
subverting" utterance, "which first says something and then, in the same image, unsays it." ${ }^{87}$ Dionysius also refers to "the ray of divine darkness, which is above

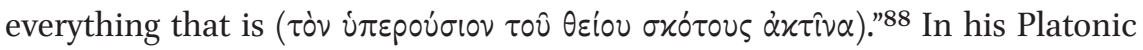
reinterpretation, the dazzlingly dangerous glory of Exodus, enveloped by its protective cloud, is used to underline the utter failure of all human speech to describe the transcendent God.

\section{The Cleft in the Rock and Gregory's Exposition of Epektasis}

In MT Exodus 33 there appears to be a contradiction between verse 11, in which God speaks to Moses "face to face (פנים אל־פנים)," and verse 20, where God states, "you cannot see my face; for no one shall see me and live." (Maybe it is

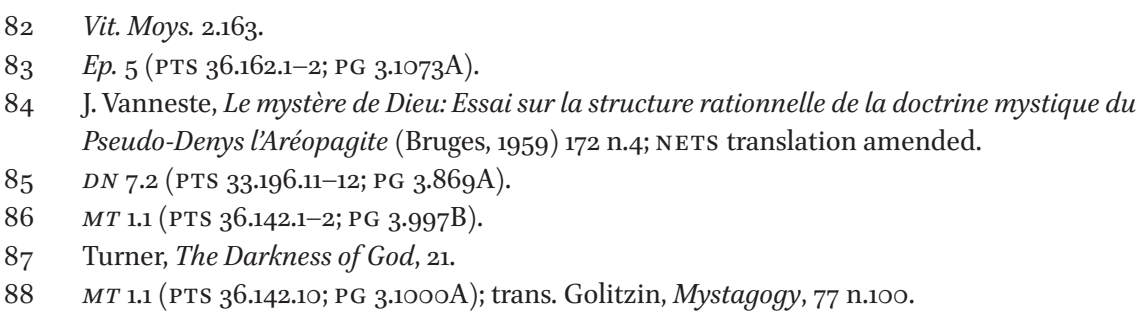


in order to play down this contradiction that the LXx translates פנים אל־פנים

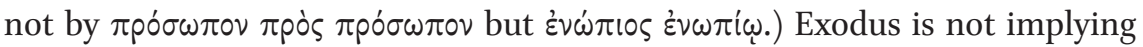
that it is impossible to see God's glory, but that no human being will survive the experience. This contrasts with Deuteronomy, which stresses "rather the inherent impossibility of God being circumscribed in any image or form." ${ }^{\prime 9}$ Paul suggests that seeing God in this life is unattainable, but that it will become possible in the world to come: "now we see in a mirror, dimly, but then we will

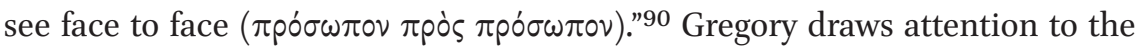
discrepancy between Exodus 33:11 and Moses' request for greater divine disclosure in $33: 13 / 18:{ }^{91}$

How does someone who Scripture says saw God clearly in such divine ap-

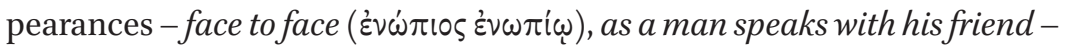

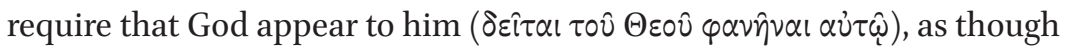
he who is always visible had not yet been seen, as though Moses had not yet attained what Scripture testifies he had indeed attained?92

Gregory uses Moses' request and God's response to generate his distinctive conception of the spiritual quest, known as epektasis, from the verb epekteinō ("to strain ahead") in Philippians 3.13. He talks of the soul "by its desire of the

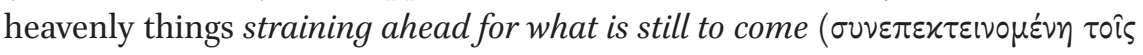
$\varepsilon \mu \pi \rho \rho \sigma \theta \varepsilon v)$, as the Apostle says;" ${ }^{\prime \prime 3}$ and argues that, despite all his achievements, Moses "still thirsts for that with which he constantly filled himself to capacity, and he asks to attain as if he had never partaken, beseeching God to appear to him, not according to his capacity to partake, but according to God's true being." ${ }^{4}$ In response, "The munificence of God assented to the fulfillment

89 Elliot R. Wolfson, Through a Speculum That Shines: Vision and Imagination in Medieval Jewish Mysticism (Princeton, 1994) 26. See Deut 4:12, 15 .

90 1 Cor 13:12.

91 There is textual variation in LXx Ex 33:18. Codex Alexandrinus follows the Hebrew: "show

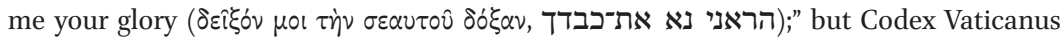

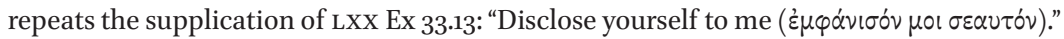
Gregory quotes LXX Ex 33:13 in Homilies on the Song of Songs 12 (GNO 6.356.7-8). He never phrases Moses' request in terms of seeing God's glory. But on the basis of God's reply (LXX Ex 33:20: "You shall not be able to see my face") he does phrase it in terms of seeing God

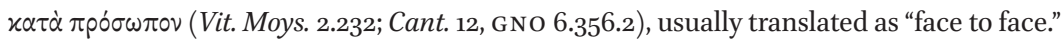
Vit. Moys. 2.219.

93 Vit. Moys. 2.225. There are also allusions to Phil 3:13 in Vit. Moys. 1.5, 2.238, 242. Gregory uses the noun epektasis in Cant. 6 (GNo 6.174.15). Vit. Moys. 2.23o. 
of his desire, but did not promise any cessation or satiety of the desire." ${ }^{\prime 95}$ In the course of his argument, he quotes Exodus 33:20, but turns the interpretation of the verse around. "The Divine is by its nature life-giving," and therefore cannot

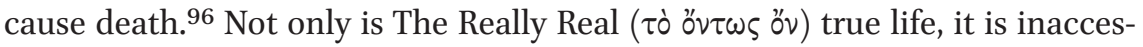
sible to our understanding. So anyone who claims that God can be known, has, by definition, turned away from The Really Real, and whatever it is they have perceived will not give them life. ${ }^{97}$ Moses, by contrast, "is satisfied by the very things which leave his desire unsatisfied." 98 In Rorem's words, "Moses does behold God but with an apophatic twist." 99 Desire is forever being filled by God, and expanding in response. As Mateo-Seco phrases it, "Every acquisition of the soul, every new progress in love, immediately turns into a new starting point towards a greater desire and greater love."100

Gregory emphasises that Moses is on a never-ending journey, each step leading to a higher one. ${ }^{101} \mathrm{He}$ ties the infinity of God, and the consequent relentless expansion of human desire, to the "place" mentioned in Exodus 33:21the place with God, he says, "is so great that the one running in it is never able to cease from his progress." $102 \mathrm{He}$ then contrasts this ever-expanding "place" with the stability of the "rock," which, following Paul, he interprets as Christ. ${ }^{103}$ The "rock" is "steadfast and immovable."104 And so we have what Gregory designates the greatest paradox of all: "the same thing is both a standing still and a moving ... I mean by this that the firmer and more immovable one remains in the Good, the more (one) progresses in the course of virtue."105 Participation in virtue is at the heart of standing/running in the "place" of God, and leads to

\footnotetext{
95 Vit. Moys. 2.232.

96 Vit. Moys. 2.233-4.

97 Dionysius makes a similar argument in Epistle 1: "Someone beholding God and understanding what he saw has not actually seen God himself but rather something of his which has being and is knowable." (PTS 36.156.8-157.1; PG 3.1065A).

98 Vit. Moys. 2.235.

99 Paul Rorem, "Negative Theologies and the Cross," Harvard Theological Review 101 (2008) $45^{1-64}, 45^{2}$.

100 Lucas Francisco Mateo-Seco, "Epektasis," in Lucas Francisco Mateo-Seco and Giulio Maspero (eds), The Brill Dictionary of Gregory of Nyssa (Leiden, 2010) 263-268, 263.

101 Gregory summarises Moses' life more than once, and the details are not the same each time; but what matters to him is the unrelenting sequence, and lack of finality. See Vit. Moys. 2.228-30; 308-13; 315-16; Cant. 12 (GNO 6.354-7); and Inscr. 1.7.51-6 (GNO $5 \cdot 43 \cdot 20-45 \cdot 4)$.

102 Vit. Moys. 2.242.

103 Vit. Moys. 2.244; cf. 1 Cor 10:4.

104 Vit. Moys. 2.244; cf. 1 Cor 15:58.

105 Vit. Moys. 2.243.
} 
the ultimate prize of becoming God's friend, "the only thing worthy of honor and desire."106

\section{Moses' Transformation and Dionysius' Exposition of “Union”}

In Exodus, the people see "the appearance of the glory of the Lord" from afar, ${ }^{107}$ but Moses alone is allowed to enter the divine cloud at the summit of Mount Sinai. Thanks to his bold request in Exodus 33:13/18, he is allowed, from the safety of the hole in the rock, to see the "back" of God's glory as it passes by. ${ }^{108}$ And when he descends from Mount Sinai, carrying a new set of tablets, something has happened to the skin of his face. ${ }^{109}$ The meaning of the Hebrew verb (קרז) is obscure, given that the root usually relates to "horn,"110 but the LXX translates it as "was charged with glory ( $\delta \varepsilon \delta \delta \xi \alpha \sigma \tau \alpha l)$," implying that Moses came so close to God that something of the radiance of divine glory was transferred onto his face. ${ }^{111}$ Paul draws on this episode in 2 Corinthians 3:7-18, arguing that the glory of Moses' face has been set aside for the greater, and more permanent, glory of Christ.

Whereas the short summary from Homilies on the Song of Songs 11, taken as definitive by Daniélou, ends with darkness, the rundown of the key stages in Moses' growth in Homilies on the Song of Songs 12 continues beyond darkness into light: "(Moses) receives the covenant; he becomes a sun, flashing unapproachable light from his countenance upon those who draw near him."112 And then comes Moses' request to see God $\varkappa \alpha \tau \dot{\alpha} \pi \rho \circ \sigma \omega \pi 0 v .{ }^{113}$ Note that Gregory has transposed Moses' transformation (Ex 34:29) with this request (Ex 33:33/18).

\footnotetext{
106 Vit. Moys. 2.321.

107 Ex 24:17.

108 Ex 33:21-23. In мт Num 12:8 it is said of Moses that "he beholds the form of the Lord

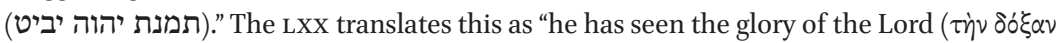

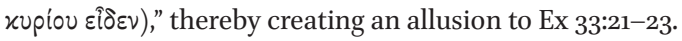

109 Ex 34:29-35.

110 Sanders uses early first-millennium Mesopotamian sources to show that "the need to translate the term as either divine radiance or physical protuberance is merely a sideeffect of our conceptual categories." Given the ancient understanding of light as material, "Moses' face could, quite literally, radiate horns:" Seth Sanders, "Old Light on Moses' Shining Face," Vetus Testamentum $5^{2}$ (2002) 400-6, 405.

111 LXX Ex 34:29.

112 Cant. 12 (GNO 6.355.12-14). Gregory's use of light imagery is explored in Martin Laird, Gregory of Nyssa and the Grasp of Faith: Union, Knowledge, and Divine Presence (Oxford, 2004) 174-204.

113 Cant. 12 (GNO 6.355.14-357.2).
} 
He also does so in Life of Moses, telling of Moses being transformed "to such a degree of glory that the mortal eye could not behold him" before he expounds on the ever-expanding "place" of God. ${ }^{114}$ But as he explains the significance of this transformation, Moses disappears, leaving a type of "the true Lawgiver," Christ: 115

For when the restorer of our broken nature ... had restored the broken table of our nature to its original beauty - doing this by the finger of God, as I said - the eyes of the unworthy could no longer behold him. In his surpassing glory he becomes inaccessible to these who would look upon him. ${ }^{116}$

Gregory is referring to the production of a new set of tablets of the covenant. The first set were supplied and written on by God (Ex 24:12, 31:18, 32:16). The second were cut by Moses (Ex 34:4); but there is some ambiguity as to whether God (Ex 34:1) or Moses (Ex 34:28) wrote on them. By making Moses a type of Christ, Gregory solves this discrepancy - if Moses is a type of Christ, who is fully God, then Moses writing on the tablets symbolises divine activity. He is also following Paul's lead in making Moses a type of Christ, although without the negative connotations. As he turns to the episode of the cleft in the rock, however, he drops the typology, and returns to Moses as "the ardent lover of beauty" who "longs to be filled with the very stamp of the archetype". ${ }^{117}$ De Andia uses the passage from Homilies on the Song of Songs 12 to define Gregory's final three stages to the spiritual journey: entry into darkness, transfiguration, and desire of vision. ${ }^{118}$ But in Life of Moses, true to the biblical text, Moses' experiences continue, including, for example, the bronze serpent, ${ }^{119}$ and the fruiting of Aaron's rod, ${ }^{120}$ until he departs "from this human life, leaving behind no sign on the earth nor any grave as a memorial of his departure," thereby preserving "an unchangeable beauty."121

114 Vit. Moys. 2.217 cf. 2.230; Cant. 12 (GNO 6.355.12-14). This is not an accurate reflection of the Exodus story, in which the Israelites do see Moses' shining face (Ex 34:30-31, 35). Gregory is no doubt influenced by 2 Cor 3:7.

115 Vit. Moys. 2.216.

116 Vit. Moys. 2.217.

117 Vit. Moys. 2.231.

118 De Andia, Henosis, 321-2, 356-7, 371.

119 Vit. Moys. 1.68, 2.272-277.

120 Vit. Moys. 1.70-71, 2.284-286.

121 Vit. Moys. 1.75-6; cf. Deut 34:6-7, Vit. Moys. 2.314. 
Gregory makes sense of Exodus 33:20, whilst still affirming God to be lifegiving, by denying that human beings ever see God. The moment of finally doing so is endlessly deferred. Perfection is continuous growth into the life of God by participation in divine virtue. But there is another way to solve the conundrum posed by Exodus 33:20. Maybe Moses withstands what no-one else could survive because he has transcended human nature. There are indeed hints of this in Exodus: when Moses collects the second set of tablets, he stays on Mount Sinai forty days and forty nights neither eating bread nor drinking water. ${ }^{122} \mathrm{He}$ then descends imbued with glory. According to Dionysius, within the darkness of unknowing, "being neither oneself nor someone else, one is supremely united ( $\dot{\varepsilon} \vee v_{\mu} \mu \varepsilon \vee \varsigma$ ) to the completely unknown by an inactivity of all knowledge."123 Similarly, in Divine Names, he talks of "the most divine knowledge of God, that which comes through unknowing" as being achieved in

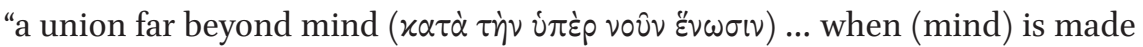

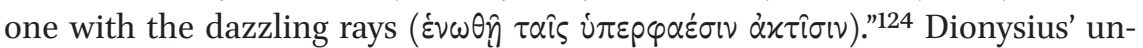
derstanding of "union ( $\tilde{v} v \omega \sigma \iota \varsigma)$ " has come under intense scholarly scrutiny. There have been debates over its debt to Neoplatonism; and a recovery of its potential liturgical basis, with "union" understood not as an intense private experience, but as an account of the Eucharistic mysteries - the celebrant, like Moses, emerging to bring God to the people. Little attention, however, has been given to its scriptural roots. De Andia argues that there is a clear difference between Gregory and Dionysius, in that Dionysius makes no mention of Moses' transformation: "une union au sein de la Ténèbre ... se substitute à la transfiguration de Moïse."125 But Moses' transfiguration, certainly as interpreted by the LXX, indicates a partaking of divine glory - in other words, some kind of union with God. And, as Turner argues, Dionysius takes the warning of Exodus 33:20 seriously:

Denys' is a mysticism which, as the psalmist puts it, "seeks the face of God" (Ps. 24, 6), but under the condition imposed by Exodus: "no one may see me and live" (Exod. 33, 20). That "death" which is the condition of "seeing" is Denys' "cloud of unknowing": a death in an apophatic darkness which will rise in the knowing-unknowing vision of God. ${ }^{126}$

\footnotetext{
122 Ex 34:28. Gregory transfers this to Moses' earlier ascent (Vit. Moys. 1.58), as does Deut 9:9.

123 MT 1.3 (PTS 36.144.13-14; PG 3.1001A).

$124 D N 7.3$ (PTS 33.198.12-15; PG 3.872B).

125 De Andia, Henosis, 357.

126 Turner, The Darkness of God, 47.
} 
For Moses to belong completely to him who is beyond everything, he had to renounce his humanity, indeed his very being.

\section{Conclusions}

A propos of mysticism in general, Katz writes,

The role of scripture, contrary to much scholarly opinion, is essential to the major mystical traditions and to the teachings and experience(s) of their leading representatives ... The most direct evidence of this deep mystical connection to and inextricable engagement with scripture is the literature produced by the major mystical traditions themselves. This literature is not ... primarily about an independent and individual religious experience but is, rather, more often than not, composed of esoteric commentaries on canonical texts. ${ }^{127}$

In situating Gregory and Dionysius within the philosophical and theological currents of their times, there is a temptation to treat their reliance on the biblical text as incidental - a marshalling of details into pre-existing schemes. Rorem writes, "Since the (biblical) model can be shaped according to the exegete's interpretive selectivity and embellishment, it takes on the interpreter's own imprint in the retelling." 128 This is of course true, but it is not necessarily a one-way process. The wording and imagery of the biblical text inspire creative thinking. As Macleod recognizes,

The biblical life of Moses offers a framework and a collection of symbols within it. It stands to the allegorist as a myth to a poet or dramatist; it can both embody and shape his thought or feeling. ${ }^{129}$

Shape as well as embody. And the contradictions, ambiguities and puzzles of the text, in particular, proved a spur to developments in mystical theology. Meaning was wrested out of recalcitrant biblical details. The various "voices"

127 Steven T. Katz, "Mysticism and the Interpretation of Sacred Scripture," in Steven T. Katz (ed.) Mysticism and Sacred Scripture (Oxford, 2000) 7-67, 8.

128 Rorem, Pseudo-Dionysius: A Commentary, 189.

129 Colin W. Macleod, "Allegory and Mysticism in Origen and Gregory of Nyssa," Journal of Theological Studies 22 (1971) 362-79, 376. 
of Exodus 19, for example, lie behind Gregory's fascination with the trumpet sound. Puzzles were elevated to paradoxes - indications that God is never subject to human logic, with the words of scripture used to undermine confidence that the essence of God could ever be encapsulated in words. The importance of Exodus 20:21 to both Gregory and Dionysius has long been recognised. But there is more to their engagement with Exodus than this. While Gregory elucidates the details of the tabernacle, and Dionysius alludes to the elders' vision, they both imagine Moses reaching the limits of the human mind - the Platonic kosmos noetos, now envisaged as the realm of angelic worship. Beyond this, as they wrestle with the enigmas of Exodus 33-4, their depictions of the spiritual journey diverge. Those chapters hold out a promise which goes beyond the humanly possible - a glimpse of the back of God's glory causes Moses himself to become glorified. Gregory resolves the contradiction between Exodus 33:11 (God speaking to Moses "face to face") and 33:13/18 (Moses asking God to disclose himself) by combining his doctrine of divine infinity with the relentless nature of the Exodus narrative, in which Moses journeys from one experience to another, with no neat climax, his desire ever expanding. "The true sight of God consists in this, that the one who looks up to God never ceases in that desire."130 To stand in the "place" of God is to experience never-ending progress in complete stability. Gregory does not, however, make any connection between Moses' experience in the hole of the rock and his subsequent transformation. Instead, he inverts the biblical order, and turns the transformed Moses into a type of Christ. It is Christ who "in his surpassing glory ... becomes inaccessible to these who would look upon him."131 Moses, by contrast, never ceases in his ascent, demonstrating that "the continual development of life to what is better is the soul's way to perfection." ${ }^{132}$

Despite simplifying the Exodus narrative into one archetypal ascent, Dionysius faithfully reflects biblical details. He is inspired by what biblical scholars classify as the theology of the Priestly source, in which the divine presence is both manifest as and veiled behind overwhelming radiance, itself protected by a dark cloud. And despite the lack of explicit reference, for his understanding of "union" he seems to draw on the biblical account of Moses transcending his humanity in a private theophany so intense that he comes to partake of divine glory. Dionysius envisages Moses, in the darkness of unknowing, "renouncing all that the mind may conceive" and belonging "completely

\footnotetext{
13 O Vit. Moys. 2.233.

131 Vit. Moys. 2.217.

132 Vit. Moys. 2.3o6.
} 
to him who is beyond everything."133 Moses is no longer himself, and "knows in a manner beyond intellect."134 This is not a substitution of "union" for transfiguration, but an interpretation of the biblical material. The culmination of Dionysius' description of Moses' ascent is not a departure from scripture, but an attempt to make sense, in the philosophical language of his day, of a puzzling but suggestive biblical passage. For to be charged with glory is indeed to experience the divine by participation, rather than by human knowing. ${ }^{135}$

\section{Acknowledgement}

This paper was first presented at Dionysius Areopagita Christianus: Approaches to the Reception and Reconstruction of the Christian "Tradition" in the Areopagitic Writings, held in Athens, February 2017. I would like to thank the organisers for the invitation, and the participants for their encouraging comments. I am also grateful to the anonymous reviewer for their perceptive suggestions.

133 MT 1.3 (PTS 36.144.11-13: PG 3.1001A).

134 MT 1.3 (PTS 36.144.15; PG 3.1001A); trans. Golitzin, Mystagogy, 39.

135 There may be mileage here for a heuristic comparison with Jewish mystical developments. As Christopher Morray-Jones observes, "there are numerous references in the apocalypses, the hekhalot writings, and the midrashic traditions of the heavenly ascent, to the metamorphosis of the mystic's body into a purified angelic or supra-angelic form of fire or light that embodies or reflects the Image of the Divine Glory." Christopher R. A. Morray-Jones, "The Temple Within," in April D. DeConick (ed.), Paradise Now: Essays on Early Jewish and Christian Mysticism (Atlanta, 2006) 145-78, 175. 